\title{
Abraham Kuyper as kerkregkundige
}

CJ Smit, Pretoria

\section{ABSTRACT \\ KUYPER AS CANONIST}

After being subjected to various influences, Kuyper opened the way to a return to the Reformed church polity of the sixteenth and early seventeenth centuries. His concept of the church was based on predestination of believers. He saw the church as the restoration of mankind in Jesus Christ. For him, the church is an organism which is visible as an institution at a particular place: namely the local church, which is fully Christ's body and is accordingly complete and independent. Concurrently, the unity of the local churches is expressed confederately when congregating in larger gatherings. The larger gathering (which is the gathering of local churches through their organs, the office-bearers) has no greater authority than the local church councils through which Christ rules his church. Office-bearers have no authority of their own, only that which is founded in ministry: their sole authority lies in ministering the Word of God. Thus, church authority is actually execution of the authority of Jesus Christ. Thence arose Kuyper's vehement opposition to all forms of human hierarchy in Christ's church. He also attempted to explain the issues of differentiation and variety in the church with his doctrine of pluriformity. Although specific aspects of Kuyper's church polity can be criticised, his lasting contribution has been the implementation of Scripture-based principles of church polity in church government - a contribution which still exerts its influence far beyond the boundaries of his country after a hundred years.

\section{INLEIDEND: 'N MAN VIR SINTESE}

As partyman was Kuyper onbetwis Abraham die Geweldige. As kerkregkundige was hy die man vir sintese, die man wat teenstellende filosofiee en teologiese strominge met sy verstommende intellektuele vermoe kon absorbeer en dit dan tot 'n nuwe weg kon verwerk. Hierin lê Kuyper se oorspronklikheid: dat hy deur sintese uit teenstrydige gedagterigtings 'n nuwe weg na die ou Gereformeerde kerkreg kon aantoon en dat hy na die eise van sy tyd op die ou leer kon voortbou. Waartoe ook die nawerking van Hegel se invloed uit sy grondgedagte van sintese, wat uit tese en antitese gebou word, nie onbetuig gebly het nie (vergelyk Van Leeuwen, 1946.49, 89, 90, 105 en Buys, 1970:175-179).

Self sẽ Kuyper (1891(a):9): "Harmonie wordt alleen uit de tegenstelling geboren..." In hierdie betekenis moet ook die slotsin in Winckel (1919:319) se biografie oor Kuyper verstaan word: "Ja waarlijk Dr. Kuyper vereenigt in zich een strijdwagen vol ruiters." 
Teenstrydige strominge wat Kuyper in sy kerkbegrip en kerkreg tot sintese gebring het, is byvoorbeeld:

die etiese en die konfessionele (vergelyk Van Leeuwen, 1946:106), die immanente én die transendente (vergelyk Van Leeuwen, 1946:88-100), die Anglikaanse en die Gereformeerde (vergelyk Kuyper, 1873:39-43), die vrye wil van die mens én die uitverkiesing (vergelyk Kuyper, 1884 (a) :28, 29, 48; 1890 (a) :9; 1890 (b) :nr. 671; 1893:132, 158-195), reveil en reformasie (vergelyk Kuyper, 1884 (a) : 117, 121-134).

\section{BEPALENDE INVLOEDE OP KUYPER}

Die belangrikste invloede, wat op die lange duur bepalend sou wees vir die kerkregtelike rigting wat Kuyper sou inslaan, word hier aangestip: - Die moderne teologie. In sy studentejare aan Leiden word die jong Kuyper onder leermeesters soos onder andere J. H. Scholten aan die moderne teologie blootgestel. Hy ontwikkel 'n afkeer aan die kerk en raak sy geloof op 'n stadium byna kwyt. In die milieu van die moderne teologie voel hy die deformasie van die kerk skerp aan: "De kerk was er geen kerk" (Kuyper, 1873:35). Tydens hierdie fase van sy teologiese vorming - in 1859 - is hy onder die invloed van Hegel en Rothe selfs van mening dat die kerk in elk geval slegs tydelik is. As gevolg van die evolusie van die godsdienstige lewe sou die kerk dan mettertyd verdwyn om plek te maak vir 'n suiwer innerlike godsdiens. Voorlopig kan die kerk nog dienstig wees, maar dit moet mettertyd in die staat as ideale organisme vir die godsdienstige en sedelike lewe van die mens opgelos word (vergelyk Doekes, 1986:36: Van Leeuwen, 1946:50: Buys, 1970:177, 178) .

Tog is Kuyper nooit geheel en al, in murg en been, deur die beginsels van die moderne teologie ingeneem nie. Hy het steeds die verlange van sy kindertyd af gehad "die mij nog altijd dorsten doet met al de dorst mijner siele" na 'n kerk waarin vaste en beslissende leiding gevind kan word. Hy het ook steeds die diepe eerbied vir die Woord van God, waarmee hy in sy ouers se pastorie opgevoed is, behou (vergelyk Kuyper, 1873:35, 43). Hierdie blywende eerbied vir die Woord sou die beslissende vertrekpunt vir die rigting van sy kerkregtelike ontwikkeling word, nadat sy groeiende afkeer aan die kerk in die milieu van die moderne teologie, sy onrustige, soekende gees eers gedwing het om ander paaie te verken.

- a'Lasco se kerkbegrip. Kuyper se bekroonde inskrywing op 'n prysvraag verwerk hy tot 'n proefskrif waarmee hy op 20 September 1862 promoveer. In hierdie proefskrif tref hy 'n vergelyking tussen die kerkbegrip van a'Lasco en die van Calvyn. Sy verset teen die Calvinisme veroorsaak 'n aanklank met a'Lasco se "immanente" kerkbegrip. Onder die "immanensie"-gedagte verstaan Kuyper God se aanwesigheid en aktiwiteit in die kerk. Hierteenoor stel hy Calvyn se kerkbegrip as "transendentaal", vanwee sy interpretasie dat Calvyn eerder op God se heiligheid as op sy liefde die klem lê. ên dat Calyn eerder die waarde van die wettiese beginsel en die gesag van die geskrewe Woord as die vrye interpretasie van die gees benadruk (vergelyk Kuyper, 1873:46; Doekes, 1986:37, 38; Van Leeuwen, 1946:50).

Die ruimte vir onderlinge liefde in die gemeente en vir vryheid van die menslike gees wat Kuyper gemeen het om in a'Lasco se kerkbegrip te 
vind, sou bepalend inwerk op sy latere stryd teen menslike hierargie en reglementère binding van die gewete in die kerk van Christus.

- Die Groningerteologie. Met sy proefskrif het Kuyper in die rigting van die Groningerteologie, soos veral deur P. Hofstede de Groot en L. G. Pareau beoefen, beweeg. In hierdie teologie het dit om die persoon van Jesus Christus gegaan, en nie om 'n Christologiese dogma nie. Die kerk is as die "Leidsvrouw tot humaniteit" bestempel. Hiervolgens lẽ die gelowiges se werklike eenheid nie in die "kerkgenootskap" nie, maar in die Kerk, dit wil sê die onsigbare kerk van ware vromes wat nie aan tyd of plek gebonde is nie (vergelyk Van Leeuwen, 1946:9-12 en Doekes, 1986:38).

Hierdie beskouing oor die kerk is deur Kuyper verwerk om later 'n invloed uit te oefen op sy idee van die kerk as organisme - 'n idee wat een van die belangrikste aspekte van sy kerkbegrip sou vorm.

- "The Heir of Redclyffe". Hierdie titel is die van 'n Engelse roman deur die skryfster Charlotte Mary Yonge, wat vir Kuyper (1873:39) "niet in waarde, maar in beteekenis voor mijn leven, naast mijn bijbel staat". Die roman bring Kuyper in aanraking met die Anglikaanse kerkbegrip soos in die High Church of England vergestalt. Die idee van 'n moederkerk wat sy lede tree vir tree van hulle jeug af lei, gryp Kuyper aan. Trouens, hier word die basis gelê vir sy latere aanvoeling van Calvyn se begrip van die kerk as ons moeder (vergelyk Kuyper, 1873:39-43 en Van Leeuwen, 1946:52, 53,59).

- Die pietistiese "konventikel"-Christene. In Augustus 1863 aanvaar Kuyper' $n$ beroep na Beesd. In die gemeente, waar die egte gloed veelal ontbreek, is daar 'n groep "malcontente" of "conventikel"-Christene wat as hoogmoedige dwepers beskou word. Van die Latynse "conventus" afgelei, beteken "conventikel" letterlik " 'n samekomsie". Klein getalle gelowiges het tot onderlinge stigting naas en later selfs teenoor die kerklike samekomste onder leiding van 'n "oefenaar" byeengekom. Die conventikel was dus in der waarheid 'n kerkie in die kerk (vergelyk Nauta, 1957: 295: Trimp en Veling, 1989:325).

Aanvanklik word Kuyper wat as 'n "moderne" dominee bekend staan, stug deur hulle behandel. By nadere kennismaking vind hy juis by hierdie groepe wat hy tot toe tevergeefs onder die sogenaamde regsinniges gesoek het: ware oortuiging, egte geestelike lewe en 'n verrassende nalewing van die geestesklimaat van die reformasie (vergelyk Kuyper. 1873:43-45, 47 en Van Leeuwen, 1946:56, 58. 59).

Hierdie gelowiges, waaronder veral 'n vrou genaamd Pietje Baltus, het 'n sterk invloed op Kuyper uitgeoefen wat medebepalend sou wees vir sy kerkregtelike groei in die rigting van die ou Gereformeerde Kerkreg van die sestiende eeu (vergelyk Trimp en Veling. 1989:322).

Die etiese en "Vermittlungs"-teoloe. Onder leiding van D. Chantepie de la Saussaye en J. H. Gunning word Kuyper vir'n tyd lank deur die etiese teoloe meegesleur. Hoewel boeiend, sou hulle kerkbeskouing vir hom uiteindelik te "relatief . . . onvast in de definitie, te vloeiend en stroomend, te gistend en zwevend . . ." wees " . . om vastheid te geven aan de geest" (Kuyper. 1873:46, 47). Op die lees van Schleiermacher ge- 
skoei, was die keı'k vir hierdie teoloë eerder 'n onbelynde liefdes- en sedelike gemeenskap as 'n institutêre gemeenskap.

Ook het Kuyper die geskrifte van die "Vermittlungs"-teoloë, waaronder H. Martensen, C. I. Nitzsch, J. P. Lange en A. Vinet, met "zeldzaam genot" verslind. Hulle kerkbeskouing was in dieselfde "spiritualistiese" en "immanente" idioom as die van die etiese teoloe (vergelyk Kuyper. 1873:47).

Na sy aanvanklike bewondering vir hierdie teologiese rigting, het Kuyper 'n felle bestryder daarvan geword, veral in sy polemiese skrywes teen J. H. Gunning. Self verklaar hy: "Juist op het stuk der Kerk waren de systemen van Gunning, de la Saussaye, Martensen en Lange het zwakst. Slechts terloops werd nu en dan dit thema door hem aangeroerd. In alles heerlijk, was in dit opzicht hun woord juist onbeslist, geen spoor zelfs wijzend, u latend in verlegenheid!" (Kuyper, 1873:47, 48).

Tog het die etiese en "Vermittlungs"-teoloe 'n aanwysbare invloed op Kuyper gehad. Sy afkeer aan hulle vloeiende en onbelynde kerkbeskouing sou daartoe meewerk om hom in die rigting van Calvyn se kerkbegrip met sy "vaste onbedriegelijke lijnen" te stuur. En tog sou hy elemente van hulle "spiritualistiese" kerkbeskouing later met die "konfessionele" beskouing van Calvyn probeer versoen in sy onderskeid van die kerk as organisme en instituut (vergelyk Kuyper, 1873:46. 47: Van Leeuwen. 1946:58, 59; Doekes, 1986:40; Buys, 1970:143).

- Die genootskaplike kerkbegrip. As 'n gebore en getoe Nederlandse Hervormer van die negentiende eeu is dit merkwaardig dat Kuyper die genootskaplike kerkbegrip reeds gedurende sy dertigerjare uit sy sisteem gekry het. Gedurende die sestigerjare van die vorige eeu gee hy weliswaar nog terdeë blyke van die kerkbegrip waarvan hy reeds van die begin van die sewentigerjare ' $n$ felle bestryder sou word. Toe was hy nog van mening dat die belang van die plaaslike gemeente aan die belang van "die kerk" opgeoffer moet word (vergelyk Kuyper, 1867:1). Hy lê klem op die onmisbaarheid van sentrale gesag in elke "kerk". "Die kerk" is vir hom die geheel wat uit dele, naamlik die gemeentes, saamgestel is (vergelyk Kuyper, 1868:30,34). Tog skemer sy latere kerkbegrip reeds deur as hy verklaar dat die eenheid van die gemeentes nie slegs in reglementêre bestuur, of in 'n administratiewe band te vinde is nie, maar in 'n geestelike grondslag as die saambindende faktor vir innerlike eenheid (vergelyk Kuyper, 1868:31.93).

- Brighton. In 1875 word 'n internasionale herlewingsbeweging in Brighton gehou. Hoewel Kuyper op die gevare van hierdie beweging wys, woon hy dit by vanwee "de ellende en onuitsprekelijke traagheid van de Protestantsche kerken". Hierdie "reveil" beskou hy van soveel betekenis as wat sedert die reformasie ongekend was, in hart en kern gereformeerd. Hoewel hy later erken dat hy hom met hierdie betowerende beweging misgis het, het die invloed daarvan nie onbetoon gebly nie. juis is sy verset teen institusionele verstarring in die kerk (vergelyk Dockes. 1986:44, 45). 


\section{KUYPER KEER TERUG NA DIE EEUE OUE GEREFORMEERDE KERKREGERING}

Kuyper se rustelose soeke na én kerklike vastigheid én geestelike vryheid kom tot uiting in 'n kerklike milieu waar die kerklewe in 'n hierargiese bestuurstelsel gestol het, hoofsaaklik vanwee die 1816-Reglement, en waar die geloof tugteloos in menslike eiewilligheid gekwyn het, hoofsaaklik vanwee die teologiese modernisme (vergelyk Kuyper, 1886 (a):2530, 32-37).

Hoewel die owerheidsheerskappy oor die kerk - volgens die 1816-Reglement - deur die 1852-Reglement gewysig is, is die kollegialistiese kerkorganisasie van 1816 steeds behou. Die Hervormde kerk het steeds sy karakter van 'n landelike genootskap behou, met 'n hoofbestuur en laer besture oor die afdelings (vergelyk Deddens, 1986:62).

Die ergste vorm van menslike heerskappy deur reglementbepalings in die kerk van Christus sou uiteindelik daartoe lei dat 'n kerkraad volkome gelikwideer word as die orgaan waardeur Christus sy kerk wil regeer. Kerkrade kon nie meer selfstandig besluit oor nagmaalsafhouding op grond van leerdwalinge nie. Trouens, die kerklike besture het 'n "oop" nagmaalstafel afgedwing. Kerkrade is ook die bevoegdheid ontneem om te weier om vrysinnige lidmate vir nagmaalsgebruik na vrysinnige gemeentes te attesteer. Later, sedert 1883, sou die ondertekeningsformulier vir predikante vervang word met slegs 'n belofte om in die bediening van die evangelie met ywer en trou werksaam te wees en in ooreenstemming met die belange van die Godsryk die van die Nederlandsche Hervormde Kerk ooreenkomstig die regiemente en verordeninge na vermoe te behartig (vergelyk Kuyper, 1886 (a) : 14-35; Kuyper en Rutgers, 1886:73-75; Bouma, 1986:15-17).

Teen die genootskaplike kerkregering waarin die kollegialisme in die vorm van menslike hiërargie welig getier het, het Kuyper hom solied vasgeloop. Sy aard en agtergrond het dit vir hom onmoontlik gemaak om hom hiermee te versoen.

Benewens die deformasie van die kerkregering kon Kuyper hom nie versoen met die heersende moderne teologie in die Nederlandsche Hervormde Kerk nie. Predikante wat in hierdie stroom beweeg het, het die ewige Godheid van Christus ontken, die uitverkiesing verwerp en die goddelike inspirasie van die Heilige Skrif verloën. Die belydenisskrifte is geignoreer. In die kruis van Golgota het sommige predikante niks meer gesien as die hoogste teken van die selfopofferende liefde van Jesus Christus nie. Die klassikale bestuur het byvoorbeeld aanklagte teen 'n vrysinnige predikant in verband met die ontkenning van die opstanding van Jesus Christus uit die dood afgewys met die motivering dat die reglemente van die kerk nie aantoon dat hierdie dwaling in stryd sou wees met die gees en die hoofsaak van die leer van die Nederduitsche Hervormde Kerk nie (vergelyk Bouma, 1986:11, 13 en Kuyper, 1886 (a):25-30)!

Kuyper het die vastigheid gesoek van 'n Skrifverankerde teologie wat definitiewe lyne vir sy kerkbegrip en kerkregering kon bied. Dit sou hy eindelik by Calvyn vind wat deur ' $n$ " . . . vasten kerkvorm zegen en 
vrede in de ontvankelijke gemoederen weten te spreiden . . " (Kuyper, 1873:47).

$\mathrm{Na}$ baie strominge waardeur Kuyper sedert sy proefskrif gewaad het, het hy vanweë sy blywende eerbied vir die Woord van God as't ware teen wil en dank Calvyn herontdek. Aan die hand van Kohlbrugge se "forschgespierde, diepgedachte levenswoorden" het hy by Calvyn se “ ". . vaste onbedriegelijke lijnen, wier spoor slechts behoefde geteekend te worden, om tot volledig vertrouwen uit te lokken . . ." uitgekom (vergelyk Kuyper, 1873:47).

Dit is of Kuyper tuisgekom het. Hy het in die huis van die vadere aangekom. Waarna sy gees op soek was, het hy in die grondlyne van die presbiteriale kerkregering van die sestiende eeu gevind. Self sê hy dat soos die vadere in die eeu van die Hervorming na die suiwere belydenis van die evangelies en 'n belydenisbegronde kerkorde teruggekeer het, het hy hom onder die seen van die Here op hulle voetspore om daardie selfde aloue suiwer evangelie geskaar om weer met die daarop gefundeerde kerkorde te leef (vergelyk Kuyper, 1886 (b) :6). Tog wou Kuyper ook nie by Calvyn tot stilstand kom nie. Vir hom sou dit op repristinasie dui. Kuyper (1873:47) was die mening toegedaan " . . dat we exegetisch, psychologisch en historisch verder moesten dan hij kwam".

As 'n nagedagte moet die motiverende invloed wat Kuyper se wapenbroer en geestesvriend, F. L. Rutgers, op hom gehad het, nooit gering geskat word nie. Met sy regspresisie en sy noukeurige navorsersgees het Rutgers die ou kerkreg van die reformasie weer opgediep, georden en aan die lig gebring. Kuyper (1883:nr. 285) het Rutgers tipeer as "verreweg de fijnste en beste kenner van ons gereformeerde kerkrecht" en na Rutgers se oorlye skryf hy oor die werk van hierdie meester van die reformatoriese kerkreg: "ge zult van bladzijde tot bladzijde bespeuren hoeveel rijker zijn aandeel in de bange worsteling was dan de mijne" (Kuyper, 1917:nr. 244).

\section{KUYPER SE KERKBEGRIP}

\subsection{Die uitverkiesing as die fondament van die kerk}

Vir Kuyper is die uitverkiesing van die gelowiges die cor ecclesiae, die hart van die kerk. Die kerk kom nie deur enige struktuur of instelling tot openbaring nie, maar deur die gelowiges. Die karakter van die kerk as 'n vergadering van gelowiges wat deur God as sy volk uitverkies is en deur Hom bewaar word, mag nie deur die kerkregering verwring of vernietig word nie. Hierdie karakter van die kerk moet juis deur die kerkregering in stand gehou word. Daarom mag die plaaslike kerk nie in 'n groter geheel opgaan, of deur reglementêre strukture gedomineer word waardeur sy karakter wat deur die uitverkiesing bepaal word, bedreig kan word nie. Die teenstrydigheid van die volkskerkgedagte, waarvolgens die lede van 'n volk kragtens hulle volkskap tot 'n bepaalde kerk gereken word, le daarin dat dit 'n ontkenning inhou van die Skriftuurlike waarheid dat die kerk nie in die wêreld gewortel is nie, maar in die raad van God (vergelyk Kuyper. 1884 (a):1-3. 48 en Buys. 1970:247-302). 
Kuyper stel die uitverkiesing as die eintlike oorsaak dat die lewe van die menslike geslag na die koms van Christus in twee bane geskei is: die nuwe lewe van die wedergeborenes en die ou lewe van die deur sonde bedorwe skepping wat nie in Christus se liggaam opgeneem is nie. Op grond van hierdie gedagte beskou Kuyper die kerk as die herskape mensheid wat as organisme met 'n eie lewensbeginsel en 'n unieke wese uit die hand van God in hierdie wêreld voortgekom het. Die wyse waarop die uitverkorenes tot die kerk vergader word, vind deur sy Gees en Woord plaas. Die kerk is in die uitverkiesing gewortel en gegrond en is derhalwe uit en deur en tot God: sy ewige gebou in die tyd (vergelyk Kuyper, 1893:132, 133; 1913:113, 315, 316).

\subsection{Die kerk as organisme en instituut}

Die onderskeiding organisme en instituut is nie maar net 'n oordeel van Kuyper se kerkbegrip nie, dit is die essensie daarvan (vergelyk Buys, $1970: 86$ ). Hierdie onderskeid is te danke aan 'n sintese wat Kuyper tussen die etiese en die konfessionele teoloe daargestel het. Die etiese teoloë het alle nadruk gelē op die kerk wat groei en ontwikkel en met 'n nuwe lewe besiel is. Hulle het hulle teen 'n vasgestelde, statiese belydenis geskaar. Hierteenoor het die konfessionele teoloe vasgestelde belydenisskrifte vir die kerk so hoog geag dat hulle geglo het dat die hele kerklike lewe daarvolgens ingerig moet word. Vir Kuyper was die organisme van die Etiese Teologie en die instituut van die Konfessionele Rigting onlosmaaklik met mekaar verbonde. Trouens, soos wese en vorm, lewe en lewensuiting, beginsel en openbaring aan mekaar verbonde is, so is die kerk gewortel as organisme en gegrond as instituut. Op die wyse beantwoord Kuyper die "spiritualiste" wat die kerk in die samelewing wil laat vervloei, sowel as die "institusionaliste" wat die kerk se wese in 'n vaste struktuur wil laat stol (vergelyk Kuyper, 1879:56, 57; 1913:323, 324: Van Leeuwen, 1946:106).

Kuyper grond sy beskouing van die kerk as organisme op sy siening dat die mensheid oorspronklik as 'n organisme geskape is. Met die sondeval is die lewensband, wat die mens aan God verbind het, verbreek. Derhalwe het die mensheid as organisme uiteengeval. Die kerk, sē Kuyper, is nou die herstelde organisme van die menslike geslag. Die wese van die kerk is dus 'n geestelike organisme en hierdie geestelike organisme kom tot tweeërlei openbaring. Eerstens word die kerk as organisme openbaar in persone. gesinne, in die volkere en in die onderskeie menslike lewensuitinge. Tweedens word die kerk as organisme openbaar in 'n eie formasie, 'n instituut wat van die organisasies van die wêreld te onderskei is. Op hierdie wyse vergader God die kerk as organisme in 'n instituut onder die heerskappy van Christus, sowel as in die maatskaplike lewe waar die gelowiges hulle roeping nakom om die hele werklikheid vir Christus te proklameer. Die organisme is vir Kuyper die wese van die kerk, die instituut is die vaste vorm waarin die organisme hom gedeeltelik openbaar. Die geinstitueerde kerk is slegs in soverre en vir solank kerk as wat dit die geestelike kerk tot openbaring bring (vergelyk Kuyper, 1898 (a) :51; 1890 (a) :4; s.j.: 1, 2, 26-31, i19-134: 1913:337; Buys, 1970:83-135: Trimp en Veling, 1989:327).

30 - In die Skriflig $1989,23(3)$ 


\subsection{Die kerk in sy onsigbare en sigbare bestaan}

Kuyper gebruik die voorbeeld van 'n mens wat deels 'n waarneembare en deels ' $n$ nie-waarneembare wese is om aan te toon dat die onsigbare en sigbare bestaanswyses van die kerk nie die eenheid daarvan in die gedrang bring nie (vergelyk Kuyper, 1884 (a) :7, 8, 30, 32).

Na sy geestelike, onsigbare sy is die kerk oor die hele aarde éen, en die hele kerk op aarde is ook eén met die kerk wat reeds in die hemel is. Die onsigbare kerk is dus die geheel van uitverkorenes van alle tye. $\mathrm{Na}$ sy sigbare sy tree die kerk stuksgewyse op bepaalde plekke aan die lig en is dus altyd plaaslik. Anders gesê: die kerk is in sy sigbare openbaring die plaaslike kerk. En omgekeerd bly die wese van 'n sigbare kerk altyd die onsigbare kerk. Die onsigbare kerk is die liggaam van Christus, dit wil sê die organiese verbinding van alle uitverkorenes deur die Heilige Gees onder Christus as hul Hoof. Die onsigbare kerk bestaan slegs op eén grond: die uitverkiesende genade van die Drieenige God (vergelyk Kuyper, 1884 (a) : 7, 8, 30, 32; s.j.:33, 34, 55-59; 1888:259, 260) .

Die sigbare kerk is dus nie die kerk in sy totaliteit nie, dit is 'n instituut van die onsigbare kerk waarbinne die diens van die Woord sy werkinge verrig. Neem die diens van die Woord weg en daar is geen sigbare kerk meer nie: die instituut verval (vergelyk Kuyper, 1893:134, 145).

Die omskrywing wat die Gereformeerde vaders van die kerk in die Nederlandse Geloofsbelydenis, artikel 27, gee, pas ewe goed op die onsigbare as die sigbare gestalte van die kerk. en geld dus eweseer vir elke plaaslike kerk as vir die kerk in die algemeen, naamlik " 'n heilige vergadering van almal wat waarlik in Christus glo, wat almal hulle volle saligheid in Jesus Christus verwag en in sy bloed gewas is, geheilig en verseel deur die Heilige Gees" (vergelyk Kuyper. 1911:129-138).

\subsection{Die kerk in sy pluriformiteit}

Volgens Kuyper vorm die herbore mensheid wesenlik een liggaam, een organiese geheel waarvan Christus die Hoof is en wat in Hom die band van eenheid belewe. Hierdie én liggaam kom egter pluriform, in verskeidenheid, tot openbaring. Dit gebeur vanwee die natuurlike verskeidenheid sowel in die stoflike werreld as in die ryk van die gees. Die diep ingrypende verskil in die bestaanswyse van die volkere maak die eenvormigheid van die openbaring van die kerk in eén instituut onmoontlik. Die nasionale en kulturele pluriformiteit het die pluriformiteit van die kerk tot gevolg. "De eenheid van de kerk ligt onwrikbaar vast in de eenheid van den Heilige Geest. maar zij spreidt zich in den geest der menschen." Kuyper gebruik die beeld van die veelvormige kleed waarin die kerk van Christus optree (vergelyk Kuyper. 1891 (a):10: 1898 (a) :52).

Kuyper keur nie elke kerklike splitsing goed nie. Hy wil dus nie sondige verskeurings in die kerk van Christus vergoeilik nie. Maar sondige verskeurings maak nog nie die beginsel van pluriformiteit as "de onafwijsbare eisch van rijke levensontwikkeling" tot niet nie. Vir Kuyper is die pluriformiteit van die kerk as sodanig nie die gevolg van die sonde nie. maar ' $n$ fase van ontwikkeling waartoe ook die kerk van Christus moet kom (vergelyk Kuyper, 1884 (a):33, 35).

In die Skriflig 1989, $23(3)-31$ 
Om die pluriformiteit van die kerk te erken sonder om die eenheid daarmee prys te gee, stel Kuyper die federatiewe kerkverband voor waarin én die selfstandigheid van die plaaslike kerk in sy eie taal en kultuur én die geestelike eenheid van plaaslike kerke gehandhaaf kan word. So, meen Kuyper, kan selfs verskillende tale en kultuurgebruike in die kerke onderhou word sonder om daarmee die geestelike eenheid in Christus tot niet te laat gaan (vergelyk Kuyper, 1884 (a) :33, 35 en Van Leeuwen, 1946:210, 211).

\subsection{Gesag in en oor die kerk}

Kuyper stel 'n inrigting, enige inrigting, sonder gesag voor as 'n muur sonder sement. Ook die kerklike instituut se kern is sy gesag. In die onmisbaarheid van kerklike gesag lê die noodsaaklikheid van die instituut (vergelyk Kuyper, 1884 (a):13). Hierdie onmisbaarheid van die kerklike gesag word deur Van Leeuwen (1946:186) aangemerk as die motief wat van die begin af tot Kuyper se voorliefde vir die vaste kerkvorm, die instituut, aanleiding gegee het.

Die enigste gesag waarop die kerk hom kan beroep, is die gesag van Jesus Christus, die Koning van die kerk. Christus oefen sy gesag deels regstreeks en deels middellik uit. Regstreeks deur die genademiddele van Woord en sakramente, en die werking van die Heilige Gees in die lede van die kerk. Middellik oefen Hy sy gesag deur mense uit wat hy tot die besondere ampte in die kerk roep (vergelyk Kuyper, 1884 (a) :42, 43, $52,53)$.

Geen gesag wat deur mense in die kerk uitgeoefen word, kom uit hulleself nie. Die ampsdraers se geroepenheid kom daarin tot uiting dat hulle slegs Jesus Christus se gesag bedien. Kuyper gebruik die voorbeeld ter toeligting: soos 'n amptenaar seer seker gesag uitoefen, maar dan nooit in eie naam nie, maar op las van sy koning en onder verantwoordelikheid aan hom, so is die gesag wat in die kerk uitgeoefen word nooit anders as amptelike en bedienende gesag nie (vergelyk Kuyper, $1884(\mathrm{a}): 52,53$ ).

Die uitoefenaar van die gesag is niks, sy koning is alles. Daarom is die gesag in die kerk heilig. Dit kom regstreeks van die koninkryk van die hemele waaroor die Seun van God as Middelaar die septer voer. Alle gesagshandelinge in die kerk is alleen gesagvol waar ooreenkomstig die Woord gehandel word. Buite die Woord om kan daar in geen kerklike handelinge dus sprake van werklike gesag, die gesag van Jesus Christus, wees nie (vergelyk Kuyper, 1886 (c): 15; Coetzee, 1980:4, 5).

\section{KUYPER SE KERKREGERING}

\section{1 ' $n$ Christusregering deur middel van die ampte}

Jesus Christus se heerskappy in en oor sy kerk word, volgens Kuyper, op twee maniere gerealiseer: in die algemene amp, of amp van die gelowiges, en in die besondere amp. Op die voetspoor van Calvyn handhaaf Kuyper die besondere amp in drieèrlei funksie, te wete die van leraars, opsieners en diakens (vergelyk Kuyper, 1884 (a):15-22).

Die algemene amp gaan die besondere amp vooraf. Die ontstaan van 'n kerkinstituut illustreer hierdie beskouing: hier rus die verantwoorde- 
likheid op die gemeenskap van die gelowiges om die besondere ampte in te stel. Trouens, die besondere ampte kan nie buite om die algemene amp bestaan nie, want dit kom daaruit voort. Tog skep die kerk nie die amptelike organe nie, maar ontvang hulle - soos die liggaam ook nie die oor maak nie, maar deur God met oog en oor versier en verryk word (vergelyk Kuyper, 1884 (a) : 18-22. 24).

Alle regeringsmag in die kerk bly in die gemeenskap van die gelowiges gewortel. Uit en deur die gemeenskap van die gelowiges kom die ampsdraers na vore. Op die gelowiges rus ook die plig om die ampsdraers weer na die regte spoor te lei as hulle sou afdwaal. Die verantwoordelikheid om Christus se gesag te bedien, berus dus by die kerk, dit wil sê die gemeenskap van die gelowiges (vergelyk Kuyper, 1884 (a) :28, 29, 41-44, $53,54,68)$. Maar vir die uitoefening van die gesag word bepaalde persone in die besondere ampte gestel. Essensieel oefen Christus sy mag in die kerk deur die amp van die gelowiges uit en organies deur die aangestelde dienaars. "Geestelijk streng monarchaal, zijnde een koninkrijk onder het absolute koningschap van den Christus, is de kerk dus in het zichtbare beslist democratisch, maar voor haar bewerktuiging aan den aristocratischen vorm gebonden." (Kuyper, 1884 (a) : 43.)

Die gemeente staan nie oor die dienaars nie en die dienaars staan nie oor die gemeente nie, maar oor beide staan Christus wat die onderlinge verhouding bepaal deur beide se gesag aan sy Woord te bind (vergelyk Kuyper, s.j. :284: 1890 (a) :10, 11, 25, 27; 1898 (a) :55; 1888:262-265; 1898 (b) :1-31).

\subsection{Die plaaslike kerk}

Kuyper (1882:nr. 236) noem die selfstandigheid van die plaaslike kerk die hoeksteen van die Gereformeerde kerkregering. Hy fundeer die selfstandigheid van die plaaslike kerk op die eksegese dat die Heilige Skrif die kerk telkens op ' $n$ bepaalde plek aandui en meervoudig na meer kerke binne dieselfde provinsie verwys, terwyl "kerk" in die Skrif nooit op 'n aantal gemeentes gesamentlik as onderdele van 'n geheel dui nie.

Elke plaaslike kerk is vir Kuyper 'n komplete kerk, volledige openbaring van die liggaam van Jesus Christus. In elke plaaslike kerk kom die universele kerk dus tot uitdrukking. Daarom is die plaaslike kerk vir Kuyper die enigste vergestalting van die sigbare kerk.

Die aaneensluiting van verskillende plaaslike kerke is sekondēr, dit rus op ' $n$ vrye konfederasie. Derhalwe is dit foutief om die plaaslike kerke as selle of dele van 'n groter geheel voor te stel. Die plaaslike kerke gaan nie op in ' $n$ landskerk-gedagte nie, maar bly selfstandig voortbestaan in ' $n$ konfederatiewe band met mekaar.

Die selfstandigheid van die plaaslike kerk beteken egter nie die outonomie van die plaaslike kerk nie. Die term outonomie, soos ook sinodonomie, word uitdruklik deur Kuyper afgewys: "Geen Synodonomie: dit is de Synode wetgeefster. Ook geen Autonomie : dit is de Kerkraad wetgever! maar Christonomie, dit is de eenige wetgever Christus onze Heer!" (Kuyper, 1882:nr. 236; vergelyk Kuyper, 1884 (a) : 19. 27, 33, 34, 35, 36, 48. 77. 147. 148. 176: s.j.:254, 255: 1890) (a) :23, 50; 1898 (a) :54, 55; 1888:260.) 


\subsection{Regering van die plaaslike kerk}

Omdat die plaaslike kerk die primére openbaring van die liggaam van Jesus Christus is, is dit vir Kuyper vanselfsprekend dat die "mag" van die kerk in die plaaslike kerk sentreer.

Die bestuur oor die plaaslike kerke word uitgeoefen deur die kerkrade wat saamgestel is uit die predikante, ouderlinge en diakens. In 'n wyer sin kom die diakens vir algemene sake (spesifieke ouderlingswerk, soos tugsake, uitgesluit) saam met die kerkraad byeen, terwyl hulle ook 'n afsonderlike vergadering vir die "bediening der tafelen" vorm.

Alle sake wat deur die plaaslike kerkraad afgehandel kan word, word afgehandel. Slegs die sake wat nie deur die plaaslike kerk afgehandel kan word nie, word saam met ander kerke in die meerdere vergadering afgehandel.

Die kerkrade beskik oor geen heersende mag nie. Hulle taak is slegs om die heerskappy van Jesus Christus te bedien. Derhalwe moet die gesag van die kerkrade as 'n bedienende gesag aangemerk word (vergelyk Kuyper, 1884 (a):71, 72, 1898 (b): 20-24).

\subsection{Plaaslike kerke in konfederatiewe verband}

Kuyper (1884 (b) : $n \mathrm{rr}, 356,1884($ a) $: 34,47,48,77)$ stel dat die eenheid van die kerk van Christus plaaslike kerke dwing om nie slegs langs mekaar te bestaan nie, maar om in eenheid met mekaar te leef. Die plaaslike kerk is immers nie dié kerk van Christus nie, maar slegs 'n openbaring van die kerk van Christus op ' $n$ bepaalde plek. Vergaderinge van kerke op ander plekke wat insgelyks openbaringe van dieselfde liggaam van Christus is, hoort dus bymekaar. Op grond van hierdie beginsel vorm die kerke 'n konfederatiewe verband met mekaar, waardeur die selfstandigheid van die plaaslike kerk nie opgehef word nie, maar juis gehandhaaf word. Trouens, die konfederatiewe gesag van die meerdere vergaderings mag nooit die karakter van die kerk, as die geinstitueerde gemeenskap van gelowiges kragtens die uitverkiesing, vernietig nie. Die meerdere vergaderings is dus in werklikheid nie afsonderlike vergaderings buite die plaaslike kerke met afsonderlike of meerdere gesag nie. Die meerdere vergaderings is gewoon vergaderings van die kerke met dieselfde gesag as die van die kerkrade wat as die organe van die plaaslike kerke byeenkom. Hierdie meerdere vergaderings waarin die kerkverband tot uitdrukking gebring word, is die klassis as die meerdere vergadering in 'n streek en die sinode as die meerdere vergadering in 'n hele land.

Die konfederatiewe kerkverband bring tot uitdrukking dat alle Gereformeerde kerke in alle lande openbaringe van die eén liggaam van Jesus Christus is. Die onmisbare grondslag vir die uitdrukking van kerklike eenheid is die eenheid in belydenis. Op die eenheid in belydenis berus alle kerklike korrespondensie, en dus ook alles wat kerkverband inhou.

Die heersende band met betrekking tot die eenheid van die kerke, sodat die kerke nie op 'n metodistiese wyse naas mekaar bestaan nie, is die Christonomie: " . . En krachtens deze Christonomie tevens de synodale band die alle kerken samenbindt. Niet dus alleen een Presbyterie. maar 
ook een Classis, en even onverbiddelijk een Synode. De eenheid onzer Nederlandsche gereformeerde kerken mag niet prijsgegeven worden." (Kuyper, 1884 (b) :nr. $356 ; 1884$ (a) :34, 47, 48. 77; 1898 (b) :36-41; 1898 (a) :55; 1890 (c) :nr. 668: 1911:170-180; 1891 (a) :7.)

\subsection{Regering van die kerke in konfederatiewe verband}

Kuyper formuleer die doel van kerkverband soos volg:

(i) die uitspreek van die gemeenskaplike belydenis van die kerke en die behandeling van gravamina daarteen;

(ii) die reel van die gemeenskaplike erediens en leerdiens;

(iii) die onderhouding van wederkerige toesig op mekaar;

(iv) die gemeenskaplike verdediging van die regte van die kerke teenoor ander partye;

(v) die beslegting van geskille tussen die kerke onderling;

(vi) die versorging van die diens van die Woord, deur die oprigting, indien nodig, van teologiese skole, die keuring van kandidate, die approbasie van beroepe dienaars en die ontslag van weggaande dienaars, ensovoorts;

(vii) die reël van die oorgang van lidmate uit die een na die ander kerk deur attestering:

(viii) die onderhouding van die gemeenskap deur afvaardiging van deputate na mekaar se vergaderinge (Kuyper, 1884 (a):78).

Die afgevaardigdes van kerke op 'n meerdere vergadering behoort volgens Kuyper nie hoofdelik te stem nie, maar kerksgewys. Die verkose moderamen val weg na sluiting van die vergadering. Die meerdere vergadering bestaan dus nie in sy bestuur voort na afloop van die vergadering nie, maar ontbind heeltemal. Wel kan die meerdere vergadering deputate benoem wat onafgehandelde sake volgens opdrag van die vergadering moet hanteer. Hierdie deputate ontvang 'n wel omskrewe mandaat van die vergadering waarbuite hulle nie mag handel nie.

Op die algemene sinode word ook reelings getref om kerklike korrespondensie met buitelandse kerke wat op dieselfde belydenisgrondslag staan, te onderhou. Op die wyse kom die ekumenisiteit van die kerk van Christus tot uiting. Nie slegs ' $n$ bepaalde land nie, maar die werreld is die territorium van die kerk.

Omdat die gesag in die plaaslike kerk sentreer, en omdat alle plaaslike kerke openbaringe van die een liggaam van Jesus Christus is, is die meerdere vergaderings waarin kerke amptelik byeenkom, eweseer gesagvol. In der waarheid verteenwoordig die amptelik gekonstitueerde meerdere vergaderings die gesag van Christus oor sy hele kerk. Maar hoewel Kuyper dus die uitsprake van die meerdere vergaderings erken, vereenselwig hy dit nooit met die van die Heilige Gees nie. Uitsprake van meerdere vergaderings is steeds onderhewig aan korreksie by wyse van beswaarskrifte en appelle, omdat daar altyd 'n kloof bly tussen die onfeilbare Woord van die Heilige Gees en die feilbare woord van mense (vergelyk Kuyper, 1884 (a) :25. 78-80, 103; 1898 (a) :5, 7; 1891 (a) :7).

\subsection{Teen menslike hierargie}

Kuyper stel dat wanneer die kerkverband tot 'n vaste liggaam met voort- 
durende bestuursliggame as die eintlike kerk georganiseer word, die geleentheid vir mense geskep word om eie mag in die kerk van Christus te bekom. En wanneer hierdie kerklike besture nie meer begaan is oor die beslissing deur die Woord van God nie en uit eie goeddunke uitsprake begin maak, word die gesag van Christus uit die kerk verdring. Waar menslike reglemente teenoor die Woord van God gehandhaaf word, word die kerk van sy gestalte as ware kerk van Christus beroof. So word die kerk prysgegee aan menslike tirannie. Hierteen moet die lede van die kerk in die amp van gelowiges in heilige protes kom. Die reformasie van die kerk begin by sy lede.

Kuyper stel teenoor alle menslike hiërargie in die kerk die heerskappy van Jesus Christus as antwoord. Die kerkregering van Christus, teenoor menslike regering, vat hy soos volg saam:

(i) dat Hy as Koning die ampte instel en die persone in die ampte benoem;

(ii) dat die kerke hulle onvoorwaardelik aan die Grondwet van sy Woord bind; en

(iii) dat die Heilige Gees in die kerkraad, in die klassis en in die sinode kom om die beraadslaginge te lei - om in der waarheid die voorsitterstoel in te neem (vergelyk Kuyper, 1888:264, 265; 1884 (a) :52, 53, 109, 110, 2114; 1886 (a) :32-44; 1887:31-46:1892:nr. 758; Kuyper en Rutgers, 1886:22-35).

\subsection{Ware en valse kerk}

Kuyper stel die kenmerke van 'n ware kerk op voetspoor van die Nederlandse Geloofsbelydenis, artikel 29, as

(i) die suiwere verkondiging van die Woord van God;

(ii) die suiwere sakramentsbediening; en

(iii) die suiwere tugtoepassing.

Maar Kuyper is geensins stellig en absoluut in sy hantering van die begrippe waar en vals nie. Trouens, hy hanteer hierdie onderskeid, wat in der waarheid meer betreklik is as wat die begrippe waar en vals 'n mens sou laat vermoed, met 'n fyn aanvoeling vir die grys gebied waarmee rekening gehou moet word tussen wit en swart (vergelyk Kuyper, 1884 (a): 167-178).

Kuyper stel dat die belydenis nie volstrek bedoel dat elke kerk wat die volle suiwerheid van een van die drie genoemde kentekens mis, daarmee as valse kerk verklaar sou kon word nie. Hy sé dat die belydenis slegs bedoel dat 'n kerk waarin die drie kentekens uitblink, sekerlik as die ware kerk erken moet word. Vals is die kerk, volgens die belydenis wat nie slegs aan een van die kentekens ontbreek nie, maar wat aan homself en sy besluite meer mag en gesag toeken as aan die Woord, wat dus meer op mense as op Christus vertrou en dié vervolg wat volgens die Woord van God heilig wil lewe (vergelyk Kuyper, 1884 (a):173).

Onder die noemer "valse kerk" onderskei Kuyper tussen 'n wesenlike kerk van Christus wat in 'n staat van deformasie verkeer, 'n skynkerk wat opgehou het om kerk van Christus te wees omdat die deformasie daar tot op sy verste punt gevorder het en 'n wesenlik valse kerk by wie die deformasie ' $n$ mag in die hand van satan geword het om dié kerk 
te omvorm tot 'n sataniese kontra-formasie (vergelyk Kuyper. 1884 (a) :111-114).

Kuyper stel dit duidelik dat slegs 'n vergadering waarin geen lede van die liggaam van Christus meer is nie, die wese van 'n kerk verloor het. So 'n kerk wat ". . . niets dan het spotbeeld van een kerk overhield, hoe symmetrisch zuiver ze ook nog in haar instellingen sta . . " het 'n valse kerk geword. En omgekeerd, sê hy, behou 'n kerk nog sy wese as kerk solank daar 'n kring van lewende lidmate van Christus teenwoordig is, al is so 'n kerk se instellinge ook verdorwe: "Zelfs een geheel afgekapte boom behoudt nog altijd het wezen van een boom, zoolang het leven nog maar in den wortel zit." (Kuyper, 1884 (a):31.)

5.8 Die gesag van die kerk in onderskeid met die gesag van die owerheid Kuyper maak 'n onderskeid in oorsprong, wese, aard en strekking met betrekking tot owerheidsgesag en kerklike gesag:

In oorsprong: die owerheidsgesag vloei regstreeks uit die soewereiniteit van die Drieënige God, terwyl die kerklike gesag uit die Middelaar as Hoof van sy kerk voortkom.

In wese: die owerheidsgesag raak die uitwendige lewe na liggaam, reg en besit, terwyl die kerklike gesag op die inwendige mens betrekking het, na sy geestelike bestaan.

In aard: die owerheidsgesag is 'n gesag van heerskappy wat met geweld dwing, terwyl die kerklike gesag nooit anders as 'n amptelike of bedienende gesag is nie.

In strekking: die owerheidsgesag het die instandhouding van die geregtigheid en die eer van God in hierdie lewe ten doel, terwyl die keklike gesag die verheerliking van God in die bediening van die uitverkorenes met die hemelse geluksaligheid ten doel het (Kuyper, 1884 (a):56).

Hieruit volg dat (i) alle kerklike mense as burgers van die staat aan die staatsgesag onderhorig is, ongeag of die staatsowerheid uit gelowige of ongelowige mense bestaan en

(ii) dat die owerheid as owerheid in geen enkele opsig, of onder watter naam ook al, in die kerk enige gesag mag uitoefen nie.

Die staat en die kerk se gesagsterreine is dus volstrek geskei. Kerklike gesag is nooit dwingend, heersend nie, maar altyd bedienend. Trouens, dit is Christus self wat die gelowiges deur sy Gees en Woord daartoe lei om onder sy gesag in die kerk te buig. Die kerk is dus volledig 'n monargie, maar 'n unieke monargie, waarin die Koning van die kerk regeer deurdat Hyself die harte van sy kinders aan Hom gehoorsaam maak (vergelyk Kuyper, 1884 (a) :56-59; 1891 (b) :nr. 681; 1890) (a) :10;1890 (d):nr 674: $1890(\mathrm{e}): \mathrm{nr} .636 ; 1890(\mathrm{f}): \mathrm{nr} .638)$.

\subsection{Kerkregering en kerkorde}

Vir Kuyper kom dit nie op maatreels vir orde in die kerk aan nie. maar op beginsels vir kerkregering. Die beginsels vir kerkregering kom uit die kerkreg wat, volgens hom, uitsluitlik oor kerklike regsverhoudinge handel. Hierdie kerklike regsverhoudinge word deur mense vir die diens van die kerk in die lewe geroep, soos dit deur ('hristus in sy Woord 
gemagtig word. Die kerkreg geld die kerk as instituut en nie die geestelike sy van die kerk as sodanig nie (vergelyk Kuyper, 1884 (a) :133; 1890 (a):5).

Alle regte en bevoegdhede wat in die kerk van Christus uitgeoefen word, wortel in Christus en is dus volkome aan sy Woord gebonde. 'n Institutêre kerk mag in werklikheid dus nooit 'n eie reg wil skep nie, maar hy behoort die bevoegdhede wat hy van Christus ontvang het, slegs te reahseer en volgens die eis van die Woord te reel. Regte van die kerk en regte van ampsdraers kom nie van die instituut af nie, maar van Christus deur sy Woord (vergelyk Kuyper, 1890 (a):5; 1891 (c):nr. 682).

Byna die hele kerkregering, en derhalwe die kerkorde, het die uitsluitlike doel om die prediking en die sakramente suiwer te hou. "Neem uit de kerkenorde uit, wat op deze beide betrekking heeft, en bijna heel uw kerkenorde valt weg." (Kuyper, 1888:262.)

Die Gereformeerde kerkreg, teenoor bykans elke ander kerkreg, aktiveer die geestelike lewe van die kerk deur die lede van die kerk en die ampsdraers voortdurend aan die Woord van God te hou (vergelyk Kuyper. s.j.: 292, 293).

\subsection{Voortdurende reformasie}

In sy stryd om kerkherstel het Kuyper steeds beklemtoon dat die roeping tot reformasie deur alle tye en omstandighede ewe dringend bly. Soos daar by die individuele gelowige daagliks bekering moet plaasvind, so moet die kerk van Christus in sy sigbare verskyning op aarde hom aan voortdurende reformasie onderhewig stel. Hierdie plig tot reformasie bly voortduur omdat die kerk in hierdie sondige, onvolmaakte wêreld leef en vanweë die sonde altyd trekke van deformasie sal toon. Met die onheilige en onware wat die kerk in hom omdra, mag nie stilswyend genoee geneem word nie. Hierby moet ons bely, sè Kuyper, dat ons nie in staat is om 'n stippeltjie heiligheid voort te bring nie. 'n Kerk wat in die duisternis teruggesink het, kan alleen deur 'n genadedaad van God weer na die lig opsien. Dit is God alleen wat deur sy Gees die nuwe lewe skenk en hy doen dit deur nuwe gehoorsaamheid aan sy Woord te skenk (vergelyk Kuyper, 1884 (a) :116-121, 157).

\section{KUYPER SE BEOORDELING VAN ANDER KERKREGERINGSTELSELS}

\subsection{Die Roomse stelsel}

Kuyper beoordeel die Roomse stelsel veral teen die agtergrond van sy beskouing van die kerk as organisme en instituut. In die Roomse stelsel vind hy ' $n$ negering van die organiese karakter van die kerk ter wille van 'n totale oorbeklemtoning van die kerk se institusionele karakter. Hy tipeer die Roomse stelsel in vier hooftrekke:

(i) dat eén regering vir die hele sigbare kerk op aarde in die lewe geroep word;

(ii) dat die kerk in stande van geestelikes en leke verdeel word en dat die leke geheel en al buite die kerkbestuur gelaat word;

(iii) dat die Roomse kerkregering in beginsel streng monargaal is; en

(iv) dat die gesag van die kerk oor die staat gevestig word. 
Die Roomse kerk beoog éen regering vir die hele wéreldkerk, en maak hom daarom los van nasionale eiendomlikhede. Hy negeer die organiese eenheid van die kerk in Christus deurdat hy 'n kerkeenheid deur 'n uitwendige band instrumenteel wil waarborg. Hierdeur word die geestelike karakter van die kerk in 'n groot mate prysgegee.

Omdat die leke-element vanself nasionale verskille in die kerkregering sou laat indring, is dit nie die leke, maar die geestelikes wat in die kerkregering deel. Die geestelikes kan buitendien buite die nasionale band te staan kom, veral deur invoering van die selibaat.

Die konsiliestelsel is onmagtig om die eenheid van die wêreldkerk uit te druk. Slegs die pouslike sisteem is daartoe bekwaam. In die konsilie kom altoos weer nasionale onderskeidings na die oppervlakte. terwyl nasionale verskille slegs in die pous wegval. Eindelik is die band in Christus nooit in die konsilie te vind nie, maar slegs in die pous. Vandaar die streng pouslik-monargale sisteem

Omdat die Roomse kerkregering die kerk met die koninkryk van God identifiseer, kan geen mag bokant die kerk geduld word nie. Daarom beoog die Roomse kerkregering om die gesag van die kerk oor die staat te vestig (vergelyk Kuyper, 1884 (a):44, 45; 1890 (a):21, 22)

\subsection{Die Lutherse en Erastiaanse stelsels}

Vir Kuyper is die opvallende tekortkoming van die Lutherse stelsel veral die aansluiting by die Erastiaanse of Remonstrantse stelsel wat die ontkenning van kerklike gesag inhou. Die Lutherse stelsel word ook die territoriale sisteem genoem, omdat die eén wêreldkerk opgedeel word in soveel brokstukke as wat daar vorstelike territoriums is, om dus landskerke te vorm, elkeen onder die eie soewereiniteit van die territoriale vors.

Hiervolgens sou Christus sy gesag oor sy kerk in die hande van die vors van die land gelè het: "Wie heer is in het land zet den godsdienst naar zijn hand." (Kuyper, 1884 (a):46.) Die kerk het as kerk geen eie gesag nie. Vandaar die verset van die remonstrante teen 'n algemene sinode aan die begin van die sewentiende eeu en hulle pleidooi vir 'n territoriale of provinsiale sinode. Vandaar ook hul verset teen die invoering van die tug, waarvoor hulle die kerk nie bevoegd geag het nie. Kuyper sien 'n sterk invloed van die territoriale en die Erastiaanse stelsels in 'n remonstrantse $\sin$ in Nederland aan die begin van die negentiende eeu met die invoering van die 1816-Reglement: vir die hele territorium moes die kerk eén wees. onder een sentrale bestuur: die dominee-stand moes die toon aangee, die leke-element het nie meegetel nie; die Algemene Sinodale Kommissie het die Lutherse Konsistorie gevorm; alle optrede van die kerk moes bloot vermanend wees; alle skakeringe van belydenis moes geduld word. sodat die gesag van die kerk insake die leer nie weer sou ontwaak nie (vergelyk Kuyper, $1884($ a) : 46, 47).

\subsection{Die Independentiese of Kongregasionalistiese stelsel}

Kuyper spreek 'n bepaalde waardering uit vir die Independentiese kerkregering. Hy ken aan hierdie stelsel die verdienste toe dat die ont wikkeling van die (alvinisme hierdeur tot op sekere punte in suiwer bane gelei 
is. Dit geld die siening dat die hart van die kerk die uitverkiesing is, dat die norm van die kerk die Woord van God is en dat die selfstandigheid van die plaaslike kerke sowel as die konfederatiewe verband van plaaslike kerke gehandhaaf word.

Waarin die Independente egter afwyk van die Gereformeerde kerkregering is die volgende:

(i) Die uitgangspunt van die stelsel is nie die plaaslike kerk nie, maar elke groep gelowiges wat hulle kerklik organiseer. So 'n groep heet 'kongregasie'.

(ii) Nie slegs die kerklike gesag in algemene sin nie, maar ook die besturende gesag berus by die lidmate. Hiervolgens het die gemeente, en nie die kerkraad nie, beslissende gesag in alle sake.

(iii) Die onderskeid tussen lerende en regerende ouderlinge word opgehef, sodat elke ouderling 'n leraar kan wees en dus ook lewenslank in die amp sou dien.

(iv) Meerdere kerke hou konferensies en nie gesagvolle meerdere vergaderings nie. Hiervolgens word aan die gesag van Christus oor die hele kerk, en derhalwe die tug van meerdere kerke waardeur die enkele kerke op die pad van die Woord gehou word, tekort gedoen.

(v) Alle reg van die kerk om die waarheid van die Skrif teen ketterse opvattinge deur belydenis, kategismus of liturgiese formuliere te handhaaf, word betwis. Die Skrif moes volgens die sisteem 'n "simbool" van eenheid bly.

Kuyper se kritiek is dat die Independentisme feitelik 'n poging is om die sigbare gestalte van die kerk tot 'n skadu te herlei en hom heeltemal terug te trek in sy geestelike karakter as vergadering van die uitverkorenes. Dientengevolge word die regsfeer van die kerk van Christus teruggedwing agter die gemeenskap van die gelowiges (vergelyk Kuyper, 1884 (a) :50, 51).

\subsection{Die Kollegialistiese stelsel}

Vir Kuyper is die kollegialistiese stelsel niks anders as die toepassing van die gedagtes van die Franse Rewolusie op die kerk nie. Die leer van die volksoewereiniteit as bron van alle gesag in die kerk van Christus, beskou hy as die hoofkenmerk van hierdie stelsel.

Die naam 'kollegiaal' dui op vereniging en is ontleen aan die wet op verenigings wat in die heidense Rome bestaan het. Die Collegia licita was die geoorloofde verenigings wat deur die wet erken is.

Die soewereine gesag van Christus word hier losgelaat, die Woord het nie meer outoriteit nie en menslike hiërargiee heers in die kerk van Christus. Die waarheid word bepaal en die gesag word uitgeoefen deur die meerderheidstem. Indien die helfte plus een vir Jesus Christus is, is die kerk Christelik, maar indien die meerderheidsuitslag anders val, kan die kerk geheel en al van sy Christelike karakter afstand doen. Die kollegiale stelsel kan hom soos 'n verkleurmannetjie skik na gelang van die heersende omstandighede. Want die outoriteit van Christus word verruil vir die outoriteit van die vrye wil van mense (vergelyk Kuyper. 1884 (a) :51, 52; 1890 (a) :35-37). 


\section{SAMEVATTEND: KUYPER AS KERKREGKUNDIGE IN PERSPEKTIEF}

Hoewel Kuyper deur sy vormingsjare as kerkregkundige aan baie teenstrydige invloede blootgestel was - en waarvan sommige se nawerking later nie onbetoon gebly het nie! - moet die ou Gereformeerde kerkreg van die sestiende en begin sewentiende eeu as sy eindelike heenkome aangemerk word. Kuyper was in 'n tyd van kerklike verstarring en geloofstagnasie én die ontwerper én die hoofbouer van die pad terug na die wortels van die Gereformeerde kerkreg.

Calvinis wou hy nooit wees nie, maar vanweë sy eerbied vir die Woord van God kon hy kwalik anders as om Calvyn se grondslae sy vertrekpunte te maak. Hy was dus geen naskrywer van Calvyn nie. Op 'n eie wyse het hy die ou Gereformeerde kerkreg vir sy tyd vertolk en 'n eie weergawe met duidelike eie aksente daaraan gegee.

Kritiek is daar wel (vergelyk onder andere Bavinck, 1883:555; Ten Hoor, 1890:11. 21, 37-42, 49, 90, 109-154; Beuker, 1890:87-100. 413, 551, 552; Doekes, 1913:443-450; Haitjema, 1931:340-345; Schilder, 1933-1934: 138, 146-202; Buys, 1970: 150,151; Van Wyk, 1968:16; Batteau. 1987:188-218; Douma, 1984:119-135: Deddens, 1986:95: Trimp en Veling. 1989:335). Kuyper het sy beskouing oor die aard en die wese van die kerkreg nie voldoende uit die Skrif gefundeer nie - ondanks die magistrale "Encyclopedie der Heilige Godgeleerheid". Hy het kerkreg gesien as die teologiese wetenskap wat slegs "met die kerk se regshandelinge en regsbetrekkinge te doen het wat mense ten dienste van die kerk daarstel" (vergelyk Kuyper, 1890 (a):5). Hierdie verskraling, omdat hy kerkreg nie wesenlik as God se reg vir sy kerk in alle fasette en in elke opsig van die kerklike lewe gesien het nie, het daartoe gelei dat Kuyper - mede vanweë verskeie invloede in sy jonger lewe homself byvoorbeeld veroorloof het om sulke konstruksies soos die kerk as organisme en as instituut te ontwerp. Juis vanweë die genoemde invloede op hom, het hy dikwels sy uitgangspunte in filosofiese konstruksies gevind waarna hy dit met die Woord van God probeer versoen het (vergelyk Van Leeuwen, 1946:221). Hierdeur het daar plek-plek skadukolle op sy waardevolle teologiese werk geval. Dit laat Haitjema uit 'n Hervormde gesigspunt skerp opmerk dat die kultuurfilosoof Kuyper nie met die teoloog Calvyn vergelyk kan word nie (vergelyk Haitjema, 1931:340, 341, 344, 345).

Kuyper se indeling van die kerk as organisme en instituut, onsigbare en sigbare kerk, is in 'n sekere sin 'n teespraak op die eenheid van die kerk. Dit is geen leerstuk van die kerk in die konfessionele sin van die woord nie, maar 'n vinding uit die vrugbare gedagtewêreld van Kuyper self. Ten Hoor (1890:21-90) meen dat Kuyper die kerk as instituut en die kerk as organisme so van mekaar skei dat dit in werklikheid twee kringe van gelowiges word. So afsonderlik funksioneer hierdie twee kringe dat die organisme nog waar kan wees in 'n heeltemal vervalste instituut. Eweseer besit die onsigbare en die sigbare kerk elkeen 'n eie wese, sodat dit eintlik twee kerke is. Want die sigbare kerk is nie altyd die sigbare sy van die kerk nie, maar 'n afsonderlike "kring" in onderskeid met die "kring" van die onsigbare kerk. Omdat Kuyper onsigbare en sigbare kerk nie duidelik as tweeerlei beskouingswyse van een en dieselfde kerk 
formuleer nie, funksioneer hierdie twee begrippe veelal los van mekaar, selfs teenoor mekaar, as wese en formasie, organisme en instituut, plaaslike en universele kerk (vergelyk Buys, 1970:150, 151: Van Leeuwen, 1946:223-225). Douma (1984:133) stel insgelyks die onhoudbaarheid van Kuyper se organismegedagte en tipeer dit as negentiende eeuse romantiek "wat stukkend breek op die feite".

Bavinck gebruik ook die begrippe organisme en instituut, maar kennelik anders as Kuyper. Vir hom is die organisme identies met die sigbare kerk, naamlik die vergadering van die gelowiges. Organisme en instituut dui vir hom nie twee verskillende kringe aan nie, maar twee beskouingswyses van dieselfde sigbare kerk: "Onjuist is daarom ook de meening, dat de kerk alleen zichtbaar wordt in het instituut, in ambt en bediening. in Woord en sacrament, in eenigen vorm van kerkregeering. Ook wanneer dit alles weggedacht wordt, is nochtans de kerk zichtbaar. Want elke geloovigen openbaart zijn geloof in belijdenis en wandel op ieder terein van het leven, en alle geloovigen saam staan met hun geloof en leven tegen de wereld over." (Bavinck. 1911:331.)

Van Wyk (1968:16) bestempel Kuyper se onderskeiding van instituut en organisme as onhoudbaar. Hy vind dit geen Bybelse onderskeiding nie, maar wel die vrug van teologies-dogmatiese besinning. Hy beskou die "kerk as instituut" ook as 'n organisme en dat "die kerk as organisme" ook institutère vorms aanneem. Met hierdie onderskeid "ontkom ons nouliks aan die Roomse dualisme van 'n Sondagkerk (instituut) en 'n Maandagkerk (organisme)"'. In die plek van die onderskeiding organisme en instituut wil Van Wyk liewers teologiseer met die veel helderder en sprekender - Bybelser - begrippe "kerk koninkryk . . . Enersyds produseer die Koninkryk die kerk. andersyds introduseer die kerk die Koninkryk" (Van Wyk, 1968:16).

Bavinck (1883:555) spreek ook kritiek uit teen Kuyper se voorstelling van die kerkverband. In die grondlyn dat die plaaslike kerk 'n openbaring van Christus se liggaam is, en nie sy wese van die algemene kerk of die kerkverband ontvang nie, is Bavinck dit met Kuyper eens. Ook die selfstandigheid van die plaaslike kerk stem Bavinck heelhartig toe, maar hy reken dat Kuyper eensydige nadruk daarop lê ten koste van die krag en die betekenis van die kerkverband. Die eenheid en solidariteit van alle kerke kom nie genoeg tot hulle reg nie. Ewemin as wat 'n plaaslike kerk deur sy verband met ander kerke ontstaan of bestaan, kan hy opsigself sonder die ander kerke volkome gaaf wees as kerk van die Koning wat ook Koning oor die ander kerke is (vergelyk Deddens, 1986:95 en Van Leeuwen, 1946:228-230).

Ook Kuyper se pluriformiteitsleer, wat 'n poging is om 'n antwoord te gee op die vraagstuk van die kerk in sy gedifferensieerde verskeidenheid, het ernstige kritiek ontlok. Schilder (1933-1934:138, 146-202) laat hom skerp hieroor uit. Hy meen dat die pluriformiteit nie die naam van leer of teorie verdien nie, en niks anders is as 'n gedagtevlug om aan ernstige moeilikhede, wat die verdelinge en die verskeuringe in die kerk betref, te ontkom nie: "een mooiklinkend woord voor een lelijke zaak" (vergelyk Van Leeuwen. 1946:227). Douma (1984:135) sluit hierby aan in sy beoordeling 
van Kuyper se pluriformiteitsleer. Hy noem dit "sterk speculatief" en "onaanvaardbaar" omdat die kerke nie soos die fraaie kleure van 'n verskeidenheid blomme en een blombedding leef nie, maar in leuen en waarheid teen mekaar opbloei (Douma. 1984:134).

Om egter af te sluit op ' $n$ toon wat Kuyper in nagedagtenis waardig mag wees: éen van die glansryke winspunte van Kuyper se kerkreg is sy volstrekte erkenning van Jesus Christus as Koning van die kerk aan wie alle menslike oorwegings onderhewig gestel moet word. Van hierdie fundamentele vertrekpunt moet Kuyper se hewige verset teen enige vorm van kollegialisme verstaan word, veral teen die genootskaplike beskouing van die kerk waarin die kerkverband bo die Woord en die belydenis gestel word. Kuyper vind die eenheid van die kerk nie in eén landskerk, nie in institutēre eenheid of in reglementêre bande nie, maar slegs in die eenheid van belydenis. 'n Eenheid dus in Jesus Christus as Koning van sy een kerk op baie plekke. Ook het Kuyper die heersende kerkbegrip van sy tyd teruggelei van strukture buite die gelowiges na wat dit is: 'n vergadering van gelowiges in Christus.

Kuyper se blywende verdienste, waarom hy na 'n honderd jaar - ver buite die grense van sy land - steeds beduidende invloed uitoefen, is die pad wat hy oopgemaak het na die ou Gereformeerde kerkreg van die sestiende en die begin van die sewentiende eeu. Van die beste waarmee hy vorendag gekom het, is die selfstandigheid van die plaaslike kerk - duidelik uit die ou kerkordes, meen ek -, die aard van die gesag en die wyse van die bediening in die kerk, die konfederatiewe aard van die kerkverband en die roeping tot voortdurende reformasie. En die beste van Kuyper, man vir sintese, ontwerper en bouer van 'n pad, is goed vir die kerk om - gereformeerd - mee te kan lewe. In diens van die Koning van die kerk.

\section{BIBLIOGRAFIE}

Bavinck, H. 1911. Gereformeerde Dogmatiek IV, 2de hersiene en vermeerderde druk. Kampen: Kok

1883. Reformatie der kerken. De Vrije Kerk. Vereeniging van Christelijk Gereformeerde Stemmen, IX, p 542-575.

Batteau. 1987. De theologie van Abraham Kuyper: een beoordeiing. Radix. (13) 4. p 188-218.

Beuker. H. 1890. Het Tractaat van de Reformatie der kerken en het artikel van ds Ten Hoor. De l'rije Kerk. Vereeniging van Christelijk Gereformeerde Stemmen. XVI, p 87 en verder.

Bouma, H. 1986. Wederkeer in Doleantie. (In Deddens, D en Kamphuis, J, red. Doleantie-Wederkeer. opstellen over de Doleantie van 1886. p 9-33. Haarlem: Vijlbrief)

Buys. PW. 1970. Iie ekklesiologiese onderskeiding organisme en instituut as antwoord op die problematiek van die volkskerk. (Proefskrif (ThD) - PU vir CHO)

Coetzee. PJ. 1980 I uther. Kuyper en ons: 'n perspektief op die roeping tot reformasie Potchefstroom: PU vir (HO

Deddens. D. 1986. Het Doleantiekerkrecht en de afgescheidenen. (In Deddens. D en Kamphuis. J. red. Doleantie Wederkeer, opstellen over de Doleantie van 1886 . p 57-150. Haarlem: Vijlbrief)

Doekes, ( 1913 . Een averechtsche bewijsvoering Gereformeerde Theologisch Tijdschrift, XIII, p 443-450

Doekes. L. 1986. 'Het is mijn moeder!' (In Deddens. D en Kamphuis J. red. DoleantieWederkeer, opstellen over de Doleantie van 1886. p 35-56. Haarlem: Vijlbrief)

Douma. J 1984. Politieke verantwoordelijkheid Kampen: Van den Berg 
Haitjema. ThL 1931. Abraham Kuyper und die Theologie des holländischen Neucalvinismus. Zwischen den Zeiten, IX, p 331-354.

Kuyper, A. 1917. Bij het afsterven van mijn trouwen vriend Rutgers. (In De Heraut, nr 244. 25 Maart).

1913. Predicatien in de jaren 1867 tot 1873 tijdens zijn predikantschap gehouden te Beesd, te Utrecht en te Amsterdam. Kampen: Kok.

1911. Pro Rege: of het koningschap van Christus, dl. 2. Kampen: Kok.

1898 (a). Het Calvinisme. Zes Stone-lezingen. Amsterdam: Hoveker en Wormser.

1898 (b). Van het kerkelijk ambt. (In Gereformeerde Stemmen uit vroeger en later tijd. p 1-45. 2de Serie, nr 1, September).

1893. E Voto Dordraceno: toelichting op den Heidelbergschen Catechismus, dl II. Amsterdam: Wormser.

1892. In De Heraut, nr 758. 3 Julie.

1891 (a). Calvinisme en Revisie. Amsterdam: Wormser.

1891 (b). In De Heraut, nr 681. 11 Januarie.

1891 (c). In De Heraut, nr 682. 18 Januarie.

1890 (a). Seperatie en Doleantie. Amsterdam: Wormser.

1890 (b). In De Heraut, nr 671. 2 November.

1890 (c). In De Heraut, $\mathrm{nr} 668.12$ Oktober.

1890 (d). In De Heraut, nr 674. 23 November.

1890 (e). In De Heraut, nr 636. 2 Maart.

1890 (f). Collegiaal stelsel. In De Heraut, nr 638. 16 Maart.

1888. Het werk van den Heilige Geest, dl I. Amsterdam: Wormser

1887. Derde Referaat: Wat ons tegenover de tweede hierargie te doen staat (In Rutgers, FL, De Savornin Lohman, AF, Kuyper A, red. Gereformeerd kerkelijk congres: het juk der tweede hierargie. Drie referaten. p 31-46. A'dam: Wormser). 1886 (a). Het dreigend conflict: memorie van de gevolmachtigde commissie uit den Amsterdamsche kerkeraad ter voorlichting der gemeente in zake de attesten. Amsterdam: Kruyt.

1886 (b). Afwerping van het juk der Synodale Hierargie. A'dam: Wormser. 1886 (c). Het conflict gekomen, II. Ons vrij beheer bedreigd en beveiligd. 3de druk. Amsterdam: Kruyt.

1884 (a). Tractaat van de Reformatie der kerken - aan de zonen der reformatie hier te lande op Luthers vierde eeuwfeest. Volksuitgawe. Amsterdam: Hoveker en Zoon.

1884 (b). In De Heraut, nr 356. 14 Oktober.

1883. In De Heraut, nr 385. 10 Junie.

1882. In De Heraut, nr 236. 2 Julie.

1879. Revisie der revisie legende, met bijlagen. Voorafgaat een "Publyck epistel" met twee annexen aan JJ van Toorenenbergen. Amsterdam: Kruyt.

1873. Confidentie. Amsterdam: Hoveker en Zoon.

1868. Kerkvisitatie te Utrecht in 1868. Utrecht: Van Peursen.

1867. Wat moeten wij doen - het stemrecht aan ons zelven houden of den kerkeraad machtigen? Vraag bij de uitvoering van Art. 23. Culemborg: Blom.

s.j. Locus de ecclesia. (In Dictaten Dogmatiek, dl. IV. College dictaat van een der studenten. 2de druk. Kampen: Kok.

_en Rutgers, FL. 1886. Contra-Memorie: in zake Amsterdamsch conflict, volgens opdracht van de geschorste leden van den kerkeraad. 2de druk. Amsterdam : Kruyt.

Nauta, D. 1957. Conventikel. (In Christelijke Encyclopedie, dl II, red. Grosheide, FW en Van Itterzon, GP. 2de hersiene druk. p 295. Kampen: Kok).

Schilder, K. 1933-1934. Pluriformiteit en epigonisme. De Reformatie, XIV, p 138-202.

Ten Hoor, FM. 1890. Afscheiding en Doleantie in verband met het kerkbegrip. Leiden.

Trimp. C en Veling, K. 1989. A Kuyper. De Reformatie, weekblad tot ontwikkeling van het Gereformeerde leven, (64) 16, p 322-336, 14 Januarie.

Van Leeuwen, PA. 1946. Het kerkbegrip in de theologie van Abraham Kuyper. Franeker: Wever.

Van Wyk. JH. 1968. Hoeveel kerkbegrippe is by ons in swang? In die Skriflig, (2) , 7 p 12-26. Augustus - September

Winckel, WFA. 1919. Leven en arbeid van dr. A. Kuyper. Amsterdam: Ten Have. 